\title{
MANAJEMEN RISIKO KESELAMATAN DAN KESEHATAN KERJA (K3) PADA HOTEL WHIZ PRIME DALAM PARTISIPASI PENCEGAHAN COVID-19
}

\author{
Ranti Komala Dewi ${ }^{(1) *}$, Fardinal $^{(2)}$ \\ (1) Program Studi Usaha Perjalanan Wisata, Politeknik Negeri Padang \\ (2) Program Studi Teknik Mesin, Politeknik Negeri Padang \\ ranti_kd2@yahoo.com, fardinal@pnp.ac.id
}

Submitted: 30 September $2020 \quad$ Revised: 3 March 2021

Accepted : 10 March 2021

\begin{abstract}
ABSTRAK
Pandemi Covid-19 di Indonesia berdampak langsung terhadap industri pariwisata, khususnya industri perhotelan yang terpaksa harus tutup di Sumatera Barat dan akhirnya dapat memberikan berbagai dampak. Tujuan penelitian ini adalah mengidentifikasi pelayanan penerapan protokol kesehatan oleh staf Housekeeping dan Front Office dalam mengurangi risiko terpaparnya karyawan oleh tamu yang datang. Berdasarkan data PHRI Sumatera Barat sudah 50\% hotel harus tutup, 30\% melakukan kegiatan (50\% dengan cara merumahkan karyawan dengan sistem unpaid dan 50\% digaji), 20\% lagi masih beroperasi dengan melakukan kegiatan katering dan menjual makanan siap saji, dan menyewakan kamar untuk isolasi mandiri. Pandemi ini merupakan masalah yang serius maka hotel wajib memiliki sumber daya manusia yang memiliki pemahaman yang baik mengenai ilmu Keselamatan dan Kesehatan Kerja (K3) khususnya dalam Standar Operasional Prosedur penanganan tamu. Metode penelitian yang digunakan adalah analisis deskripsi kepada seluruh karyawan Hotel Whiz Prime Padang. Teknik pengumpulan data menggunakan teknik sampel jenuh dengan alat pengumpulan data berupa kuesioner untuk mengidentifikasi risiko. Hasil penelitian menunjukkan bahwa kegiatan pelayanan penerapan protokol kesehatan oleh staf Housekeeping dan Front Office sudah baik, namun masih ada yang perlu diperbaiki dan luaran penelitian ini berupa pengembangan Standar Operasional Prosedur.
\end{abstract}

Kata Kunci : Covid-19, Hotel Whiz Prime Padang, Keselamatan dan Kesehatan Kerja (K3), Manajemen Risiko

\section{OCCUPATIONAL HEALTH AND SAFETY RISK MANAGEMENT AT WHIZ PRIME HOTEL IN PARTICIPATION TO PREVENT COVID-19}

\begin{abstract}
Covid-19 in Indonesia gives a direct impact on the Indonesian tourism industry, particularly the hotel industry, which was forced to close in West Sumatra. The purpose of this study was to identify the implementation of health protocol services by Housekeeping and Front Office staff in reducing the risk of employee exposure to guests. Based on West Sumatra PHRI data, $50 \%$ hotels have closed, $30 \%$ are carrying out activities $150 \%$ by laying off employees with an unpaid system and 50\% are paid), 20\% are still operating by catering and selling ready-to-
\end{abstract}


eat food, and how to rent out a room for self-isolation. This pandemic is a serious problem, therefore the hotel needs to have human resources who have a good understanding of Occupational Safety and Health (K3), especially in the Standard Operating Procedure for guest handling to avoid local transmissions. In this study, the method used is descriptive analysis to all employees of the Whiz Prime Padang Hotel. The data collection technique uses a saturated sample technique with a data collection tool in the form of a questionnaire to identify risks. The results showed that the service activities of implementing health protocols by the Housekeeping and Front Office staff were good, but there were still things that needed to be improved, and the outcome of this study was the development of standard operating procedures.

\section{Keywords: Covid-19, Hotels, Occupational Safety and Health (K3), Risk Management}

\section{PENDAHULUAN}

Tingkat hunian hotel bintang di 34 Provinsi di Indonesia pada bulan Januari - Juli 2020 sebesar $32,41 \%$ atau mengalami penurunan sebesar $60,10 \%$ apabila dibandingkan tingkat hunian hotel bintang di 34 Provinsi di Indonesia pada bulan Januari - Juli 2019 lalu sebesar 51,89\% (Soehardi, 2020). Sementara ketika awal pandemi tingkat hunian kamar Hotel Bintang di Sumatera Barat pada bulan Januari Juli 2020 sebanyak 30,24 persen, ini mengalami penurunan dibandingkan dengan bulan yang sama pada tahun 2019, yaitu 51,55 persen (Kementerian Pariwisata \& Ekonomi Kreatif Republik Indonesia, 2020).

Ditengah mewabahnya pandemi Covid-19 membawa perubahan cukup signifikan pada industri perhotelan di kota Padang. Kondisi ini menuntut pihak hotel melakukan inovasi demi tetap bisa bertahan di tengah gempuran wabah virus Covid-19 (Wirawan dkk, 2020), yakni dengan adanya penawaran paket isolasi mandiri selama 14 hari oleh Hotel Whiz Prime Padang. Sementara itu, hotel lain beralih ke usaha kulinari dan ada juga yang harus tutup (Budiman, 2020). Maulana Yusran mengungkapkan bahwa 26 dari 80 hotel Sumbar sudah tutup dan anggota PHRI Sumbar membuat kesepakatan dengan pekerjanya dengan cara merumahkan karyawan untuk sementara waktu dan menghindari terjadinya pemutusan hubungan kerja (cnnindonesia, 2020).

Berdasarkan pada fenomena di atas maka perlu dilakukan penelitian yang bertujuan untuk mengidentifikasi pelayanan penerapan protokol Covid-19 oleh staf Housekeeping dan Front Office dalam megurangi risiko (manajemen risiko) terpaparnya karyawan Hotel Whiz Prime Padang dari virus Covid-19 oleh tamu yang berkunjung. Luaran penelitian adalah untuk pengembangan Standar Operasional Prosedur (SOP) yang efektif dan efisien dalam rangka pencegahan penyebaran virus Covid 19 pada divisi Housekeeping di hotel ini.

\section{TINJAUAN PUSTAKA Manajemen Risiko}

Manajemen risiko menjadi sebuah cara yang sistematis dalam memandang sebuah risiko dan menentukan dengan tepat penanganan terhadap risiko tersebut. Ini merupakan sebuah sarana untuk mengidentifikasi sumber dari risiko dan ketidakpastian (Indragiri \& Yuttya, 2018) serta dapat memperkirakan dampak yang akan ditimbulkan dan mengembangkan respon yang harus dilakukan untuk menanggapi risiko tersebut. Tindakan manajemen risiko diambil oleh para praktisi untuk merespon bermacam- 
macam risiko yang ada (Abdurrahman dkk, 2019). Responden melakukan dua macam hal tindakan dalam manajemen risiko, yaitu perihal mencegah dan memperbaiki (Ibrahim, 2011).

\section{Keselamatan dan Kesehatan Kerja (K3)}

Menurut Suma'mur (2001), "Keselamatan dan kesehatan kerja merupakan rangkaian usaha untuk menciptakan suasana kerja yang aman dan tentram bagi para karyawan yang bekerja di perusahaan yang bersangkutan". Pencegahan kecelakaan ketika bekerja dapat dilakukan dengan mengetahui berbagai risiko yang akan muncul, salah satunya melalui metode (HIRARC) Hazard Identification, Risk Assesment, and Risk Control (Ihsan dkk, 2017).

\section{Industri Perhotelan di Tengah Pandemi}

Sebagai sebuah organisasi, hotel memerlukan berbagai strategi untuk bisa bertahan hidup (Avriyanti, 2021). Menurut Sulastiyono (2006), hotel dikategorikan sebagai suatu perusahaan yang dikelola oleh pemiliknya dengan menyediakan pelayanan makanan, minuman, dan fasilitas kamar tidur kepada orang-orang yang melakukan perjalanan dan mampu membayar dengan jumlah yang wajar sesuai dengan pelayanan yang diterima tanpa adanya perjanjian khusus. Ketika terjadi pandemi, hotel dapat memberikan penawaran khusus (Ilham, 2020) dalam bentuk strategi pemasaran untuk menyediakan kamar khusus untuk ruang isolasi mandiri (Masatip, 2020) (Kaniasari dkk, 2021).

\section{Pandemi Coronavirus Disease 2019 (COVID-19)}

Pandemi Covid-19 yang melanda dunia adalah penyakit jenis baru yang belum pernah diidentifikasi sebelumnya pada manusia. Virus Corona adalah Zoonosis yang dapat ditularkan antara hewan terhadap manusia, virus penyebab COVID-19 ini dinamakan Sars-CoV-2. Penelitian menyebutkan bahwa SARS ditransmisikan dari kucing luwak (civet cats) ke manusia, dan MERS dari unta ke manusia. Akan tetapi hewan yang menjadi sumber penularan COVID-19 ini sampai saat ini masih belum diketahui (Dinas Kesehatan, 2020).

\section{METODE PENELITIAN}

Penelitian ini menggunakan metode deskriptif. Penelitian deskriptif adalah teknik yang menggambarkan dan menginterpretasikan arti data-data yang telah terkumpul dengan memberikan perhatian dan merekam sebanyak mungkin aspek situasi yang diteliti pada saat itu, sehingga memperoleh gambaran secara umum dan menyeluruh tentang keadaan sebenarnya (Kriyantono, 2007).

Objek penelitian adalah karyawan dari Hotel Whiz Prime Padang yang bertugas pada periode pandemi COVID-19. Teknik pengumpulan data, yakni dengan menggunakan teknik sampling yang melibatkan seluruh anggota populasi disebut sampling jenuh karena jumlah populasi hanya 20 orang responden. Maka, penulis mengambil data sebanyak $100 \%$ jumlah populasi yang ada pada divisi Housekeeping dan Front Office. Alat yang digunakan untuk pengumpulan data pada penelitian ini adalah dengan alat bantuan panduan wawancara dan pengambilan dokumentasi. Pengumpulan data juga dilakukan dengan kuesioner. Kuesioner atau angket, merupakan serangkaian/daftar pertanyaan tertulis ditujukan kepada responden mengenai masalah-masalah tertentu yang 
bertujuan untuk mendapatkan tanggapan dari responden tersebut. Teknik analisis data dengan menggunakan teknik persentase untuk melihat kecenderungan modus persentase yang paling besar.

\section{HASIL DAN PEMBAHASAN}

Jumlah karyawan Hotel Whiz Prime Padang yang bertugas pada periode pandemi COVID-19 dalam bagian Front Office dan Housekeeping berjumlah 20 orang. Pada penelitian ini mayoritas responden adalah Pria sebanyak $85 \%$ dan sisanya $15 \%$ adalah Wanita. Rentang usia responden antara 17-29 tahun sebanyak 95\%, dan hanya $5 \%$ berusia antara 30-39 tahun. Pendidikan terakhir mayoritas pengisi kuesioner adalah 85\% SMA/SMK, 10\% berpendidikan D1 dan sebanyak 5\% berpendidikan D4/S1. Jika dilihat dari responden dalam penelitian ini mayoritas adalah bagian Housekeeping sebanyak $70 \%$ dan $30 \%$ adalah bagian Front Office.

\section{A. Manajemen Risiko Keselamatan dan Kesehatan Kerja (K3) Pada bagian Housekeeping}

Housekeeping memiliki peranan penting dalam kepuasan tamu, sehingga tamu mendapatkan kenyamanan selama menginap di hotel. Selain mengedepankan unsur kebersihan, keselamatan dan keamanan Housekeeping juga harus mampu memberi jaminan bebas dari segala virus disaat kita berada dalam masa tatanan normal baru.

Protokol kesehatan Covid-19 sudah bagus dilakukan oleh staf Housekeeping, seperti pada penyediaan sabun untuk mencuci tangan di toilet umum sudah dilakukan 100\%. Selain itu, persentase yang dicapai pada tahapan yang selalu dan sering adalah membersihkan semua area hotel baik area kerja maupun fasilitas umum adalah $85 \%$ selalu dan hanya $15 \%$ menjawab sering. Pada ketersediaan hand sanitizer di lokasi yang sudah ditentukan hotel terdapat $95 \%$ selalu dan 5\% menjawab sering. Melakukan pembersihan dan disinfektan di area umum hotel, seperti lobi, toilet, ruang serbaguna, ruang pertemuan, koridor, dan lift secara berkala sudah dilakukan sebanyak $90 \%$ selalu dan hanya $10 \%$ menjawab sering. Membersihkan pegangan pintu, tangga, dan tombol lift setiap saat menjawab $80 \%$ selalu dan $20 \%$ sering. Karyawan yang bertugas membersihkan dilengkapi dengan peralatan pelindung diri, seperti masker dan cairan disinfektan sebanyak $95 \%$, dan kadang-kadang sebanyak $5 \%$.

Beberapa SOP telah dilakukan oleh beberapa staf dengan baik, yaitu pembersihan area kerja dan fasilitas umum dengan menggunakan cairan disinfektan sekurang-kurangnya dua kali sehari, terutama benda yang sering disentuh dan terdokumentasi dengan baik sebanyak $85 \%$ menjawab selalu, $10 \%$ menjawab sering, dan 5\% menjawab kadang-kadang. Pemeriksaan rutin fungsi dispenser sabun, tisu, pembersih tangan (hand sanitizer), dan pengering tangan di seluruh lokasi yang hotel tentukan 5\% yang menjawab kadang-kadang, $15 \%$ menjawab sering dan $80 \%$ menjawab selalu. Disinfektan fasilitas umum hotel dan restoran satu kali dalam setiap shift $80 \%$ menjawab selalu, $15 \%$ menjawab sering, dan $5 \%$ menjawab kadang-kadang. Desinfeksi dan pembersihan kamar tamu $70 \%$ menjawab selalu, $15 \%$ lainnya menjawab sering, dan $15 \%$ menjawab kadang-kadang. Mesin absen dengan jari dibersihkan satu kali dalam setiap shift sebanyak $75 \%$ menjawab selalu, $10 \%$ menjawab sering, dan $15 \%$ menjawab kadang-kadang. 


\section{B. Manajemen Risiko Keselamatan dan Kesehatan Kerja (K3) Pada bagian Front Office}

Font Office juga memiliki peranan penting dalam kepuasan tamu agar tamu mendapatkan kenyamanan selama menginap di hotel. Selain harus mampu memberi jaminan bebas dari segala virus disaat melakukan reservasi, Front Office juga harus mengedepankan unsur kebersihan, keselamatan, dan keamanan disaat kita berada dalam masa tatanan normal baru.

Staf Front Office sudah bagus dalam penerapan protokol kesehatan Covid-19, ini terlihat dari persentase jawaban yang mayoritas menjawab selalu dan sering. Terlihat dari ketersediaan pembersih tangan (hand sanitizer) di meja Front Office hotel dapat kita temukan karena 95\% menjawab selalu dan hanya $5 \%$ yang menjawab sering. Staf Front Office sudah meminta tamu untuk membersihkan tangannya menggunakan hand sanitizer selama proses check in dan check out, dimana $80 \%$ menjawab selalu dan $20 \%$ menjawab sering.

Memberikan informasi bahwa seluruh hotel dibersihkan sesuai SOP internal yang ada, $85 \%$ menjawab selalu, semantara $15 \%$ menjawab sering. Membuat tanda antrian tamu dengan jarak minimum antara tamu dan karyawan sejauh satu meter $95 \%$ menjawab selalu dan 5\% menjawab sering. Mengurangi kontak fisik dengan tamu dalam bentuk apapun, seperti tidak berjabat tangan, yaitu $95 \%$ menjawab selalu dan 5\% menjawab sering.

\footnotetext{
Namun masih ada beberapa staf yang belum maksimal dalam menerapkan SOP, seperti ketersediaan informasi tentang COVID-19 mengenai gejala, penyebaran, dan pencegahannya di hotel $60 \%$ menjawab selalu, $25 \%$ menjawab sering, dan $15 \%$ menjawab
}

kadang-kadang. Dalam hal menanyakan riwayat perjalanan tamu selama 14 hari sebelumnya pada formulir pendaftaran dan deteksi perjalanan hanya 50\% yang menjawab selalu, 20\% menjawab sering, dan $30 \%$ menjawab kadangkadang-kadang. Jika suhu diatas 37,3 derajat celcius maka tamu disarankan untuk mencari perawatan medis hanya $60 \%$ menjawab selalu, $30 \%$ menjawab sering, dan 5\% menjawab kadangkadang. Jika suhu tubuh normal, sebelum check in dilakukan pengisian formulir pendaftaran dan deklarasi perjalanan menjawab $65 \%$ selalu, $25 \%$ sering, dan $10 \%$ kadang-kadang.

Selain itu juga ada beberapa staf yang tidak melakukan SOP seperti membersihkan meja receptionist segera setelah setiap kali melayani tamu sebanyak 5\% dan $10 \%$ menjawab kadang-kadang, tetapi sebagian besar menjawab selalu $70 \%$ dan $15 \%$ menjawab sering. Memberi batas sesuai jarak aman minimal satu meter pada tempat duduk di lobby dan receptionist hotel, yaitu sebanyak 5\% menjawab tidak pernah dan $10 \%$ menjawab kadang - kadang, namun sebagian besar menjawab selalu sebanyak $75 \%$ dan $10 \%$ menjawab sering. Memeriksa dan mencatat suhu tubuh tamu yang memasuki hotel sebanyak $5 \%$ menjawab tidak pernah dan kadangkadang sebanyak 5\%, namun $70 \%$ menjawab selalu dan $20 \%$ menjawab sering.

\section{KESIMPULAN}

Dari data yang diperoleh serta hasil analisis yang telah dilakukan pada bab sebelumnya, dapat disimpulkan bahwa: Manajemen risiko Keselamatan dan Kesehatan Kerja (K3) pada bagian Housekeeping dalam kegiatan pelayanan dengan penerapan protokol kesehatan Covid-19 sudah baik dilakukan oleh staf Housekeeping, 
seperti pada penyediaan sabun untuk mencuci tangan di toilet umum sudah dilakukan maksimal, penyediaan cairan disinfektan di banyak ruangan hotel, dan pengecekan suhu berlapis di berbagai sudut hotel. Namun, beberapa penerapan SOP masih dilakukan oleh beberapa staf pada tahapan sepintas, yaitu membersihkan area kerja dan fasilitas umum dengan menggunakan cairan disinfektan sekurang-kurangnya dua kali sehari serta dalam hal pemeriksaan fungsi dispenser sabun, tisu, hand sanitizer, dan pengering tangan di seluruh lokasi hotel. Selain itu, disinfektan fasilitas umum hotel dan restoran satu kali dalam setiap shift, serta disinfeksi dan pembersihan kamar tamu juga belum dilakukan secara maksimal.

Manajemen risiko Keselamatan dan Kesehatan Kerja (K3) pada bagian Front Office. Persentase rutinitas staf Front Office dalam partisipasi pencegahan Covid-19 masih belum mencapai angka sempurna. Meskipun kegiatan pelayanan dengan penerapan protokol kesehatan Covid-19 sudah bagus, seperti memberikan informasi bahwa seluruh hotel dibersihkan sesuai SOP internal yang ada dan membuat tanda antrian tamu dengan jarak minimum antara tamu dan karyawan sejauh satu meter. Namun, demikian masih ada beberapa SOP yang dilakukan pada tahapan sangat minim, yaitu tidak membersihkan meja receptionist segera setelah setiap kali usai melayani tamu, tidak memberi batas sesuai jarak aman minimal satu meter pada tempat duduk di lobby dan receptionist hotel, serta tidak memeriksa dan mencatat suhu tubuh tamu yang memasuki hotel.

\section{UCAPAN TERIMAKASIH}

Penelitian ini dapat terlaksana dengan baik berkat bantuan dari berbagai pihak, untuk itu peneliti mengucapkan terima kasih kepada Politeknik Negeri Padang dan kapada GM dan staf Hotel Whiz Prime Padang.

\section{DAFTAR PUSTAKA}

Abdurrahman, A., Maniza, L. H., \& Lestari, M. (2019). Analisis Implementasi Manajemen Pengendalian Risiko Dalam Upaya Tercapainya Tujuan Organisasi (Studi Kasus Pada Kantor Wilayah Direktorat Jenderal Perbendaharaan Provinsi Nusa Tenggara Barat). JIAP (Jurnal Ilmu Administrasi Publik), 6(1), 30-38.

Masatip, A., Maemunah, I., Rosari, D., \& Anggreani, C. (2020). Analisis Strategi Pemasaran pada Hotel Inna Parapat dalam Situasi Pandemi Covid-19. Jurnal Akademi Pariwisata Medan, 8(2), 150-159.

Avriyanti, S. (2021). STRATEGI BERTAHAN BISNIS DI TENGAH PANDEMI COVID-19 DENGAN MEMANFAATKAN BISNIS DIGITAL (STUDI PADA UKM YANG TERDAFTAR PADA DINAS KOPERASI, USAHA KECIL DAN MENENGAH KABUPATEN TABALONG). Jurnal PubBis, 5(1), 60-74.

Budiman, F. (2020). Corona Mewabah, Hotel Whiz Prime Tawarkan Paket Isolasi Mandiri. [Online] Diakses dari:

PadangToday.http://www.padangto day.com/corona-mewabah-hotelwhiz-prime-tawarkan-paket-isolasimandiri/, 9 April 2020

CNN. (2020). Corona, Pengusaha Hotel Rumahkan 2.500 Karyawan di Sumbar. [Online] Diakses dari: https://www.cnnindonesia.com/eko nomi/20200408092028-92-

491498/corona-pengusaha-hotel- 
Ranti Komala Dewi, Fardinal: Manajemen Risiko Keselamatan dan Kesehatan Kerja (K3) Pada Hotel Whiz Prime dalam Partisipasi Pencegahan Covid-19

rumahkan-2500-karyawan-disumbar

Dinas Kesehatan Pemerintah Kabupaten Bantul. (2020). Mengenai Covid 19. [Online] Diakses dari: https://dinkes.bantulkab.go.id/berita /800-mengenal-covid-19

Ibrahim, J. K. (2011). Pelaksanaan Program Keselamatan Dan Kesehatan KerjaKaryawan PT. BITRATEX INDUSTRIES. Skripsi. Semarang: Universitas Diponegoro.

Ihsan, T., Edwin, T., \& Irawan, R. O. (2017). Analisis Risiko K3 Dengan Metode Hirarc Pada Area Produksi Pt Cahaya Murni Andalas Permai. Jurnal Kesehatan Masyarakat Andalas, 10(2), 179185.

Ilham, I. (2020). Kondisi Pengusaha Indonesia Ditengah Pandemi Covid-19. Civic-Culture: Jurnal Ilmu Pendidikan PKN dan Sosial Budaya, 4(1 Extra), 59-68.

Indragiri, S., \& Yuttya, T. (2018). Manajemen risiko k3 menggunakan hazard identification risk assessment and risk control (hirarc). Jurnal Kesehatan,9(1), 39-52.

Kaniasari, D., Mardotillah, M., \& Masatip, A. (2021). Penerapan Protokol Kesehatan Hotel sebagai Langkah Preventif pada Masa Pandemi. Jurnal Akademi Pariwisata Medan, 9(1), 46-52.

Kementerian Pariwisiata dan Ekonomi Kreatif Republik Indonesia. (2020). Statistik Tingkat Penghunian Kamar Hotel Bintang Tahun 2020. [Online] Diakses dari: https://www.kemenparekraf.go.id/p ost/statistik-tingkat-penghuniankamar-hotel-bintang-tahun-2020

Kriyantono, R. (2007). Teknik Praktis Riset Komunikasi. Jakarta: Kencana
Soehardi, Lina P, Diara R. (2020). Dampak Pandemik Covid-19 Terhadap Kunjungan Turis Asing dan Domestik Serta Tingkat Hunian kamar Hotel Bintang di Indonesia. Jurnal Kajian Ilmiah, 20(3), 291-308

Sulastiyono, A. (2006). Manajemen Penyelenggaraan Hotel. Bandung: Alfabeta.

Suma'mur. (2001). Keselamatan Kerja dan Pencegahan Kecelakaan. Jakarta: CV. Haji Masagun.

Wirawan, P. E., Pujiastuti, S., \& Astuti, N. N. S. (2020). Strategi Bertahan Hotel Di Bali Saat Pandemi Covid19. Jurnal Kajian Bali (Journal of Bali Studies), 10(2), 579-602. 
Ranti Komala Dewi, Fardinal: Manajemen Risiko Keselamatan dan Kesehatan Kerja (K3) Pada Hotel Whiz Prime dalam Partisipasi Pencegahan Covid-19 